A N N A LES

UNIVERSITATIS MARIAE CURIE-SKŁODOWSKA

LUBLIN - POLONIA

VOL. LXVII, 1

SECTIO G

2020

Uniwersytet Marii Curie-Skłodowskiej w Lublinie

WOJCIECH SZCZOTKA

szczotka.wojciech@gmail.com

ORCID: 0000-0001-5553-5174

\title{
Dobra osobiste uczelni publicznej
}

Personal Interests of a Public University

I.

W ostatnich latach, w szczególności po 1989 r., można zauważyć znaczący wzrost zainteresowania problematyką dóbr osobistych nie tylko osób fizycznych, lecz także - co jest przedmiotem niniejszego opracowania - osób prawnych. W konsekwencji, od tamtego czasu, następuje istotny rozwój tej tematyki, zarówno w sferze rozważań o charakterze teoretycznym, czego przejawem są liczne rozprawy naukowe, jak i w praktyce, gdzie powstała bogata baza orzecznictwa, poruszająca wiele aspektów wskazanego zagadnienia. Dokonując wstępnej charakterystyki dóbr osobistych osób prawnych, należy za A. Szpunarem odnieść się do ustaleń o charakterze bezspornym. Po pierwsze, należy do nich wskazanie, że na podstawie art. 43 Kodeksu cywilnego ${ }^{1}$ przepisy o ochronie dóbr osobistych osób fizycznych stosuje się odpowiednio do osób prawnych. W ten sposób ustawodawca wskazuje, że uznaje istnienie dóbr osobistych takich podmiotów. Po drugie, przepis ten nakazuje stosowanie do ochrony dóbr osobistych osób prawnych odpowiednio przepisów o ochronie dóbr osobistych osób fizycznych (art. 23 k.c. oraz art. 24 k.c.). Po trzecie, należy przyjąć za słuszne twierdzenie, że art. 43 k.c., w związku z zasadą odpowiedniego jego stosowania, ma charakter ramowy i nie przesądza, jakie dobra osobiste osób prawnych doznają ochrony².

1 Ustawa z dnia 23 kwietnia 1964 r. - Kodeks cywilny (t.j. Dz.U. 2019, poz. 1460 ze zm.), dalej: k.c.

2 A. Szpunar, Ochrona dóbr osobistych przystugujacych osobom prawnym, [w:] Problemy kodyfikacji prawa cywilnego. Studia i rozprawy. Ksiegga pamiatkowa ku czci Profesora Zbigniewa Radwańskiego, red. S. Sołtysiński, Poznań 1990, s. 27-28. 
W związku z powyższymi ustaleniami należy wskazać, że ustawodawca nie zdefiniował pojęcia dóbr osobistych osób prawnych, nie stworzył także ich przykładowego katalogu, tak jak to uczynił w art. 23 k.c. w odniesieniu do dóbr osobistych osób fizycznych. W judykaturze zaaprobowany został pogląd, że dobra osobiste osób prawnych to wartości niemajątkowe, dzięki którym osoba prawna może funkcjonować zgodnie ze swym zakresem działań ${ }^{3}$. Zgodnie z ugruntowanym orzecznictwem Sądu Najwyższego osobom prawnym przysługują takie dobra osobiste, jak: dobre imię (dobra sława, reputacja, autorytet), nazwa (firma), tajemnica korespondencji ${ }^{4}$. Do powyższego katalogu, za poglądami wyrażonymi w literaturze, dodaje się także nietykalność pomieszczeń, w których osoba prawna realizuje swoje zadania ${ }^{5}$, a także - co jednak wciąż jest sporne - prywatnośćc $^{6}$ Wykluczone natomiast zostało przypisywanie osobie prawnej takich dóbr osobistych, które związane są z posiadaniem sfery odczuć. Dominujący jest pogląd, że takie dobra, jak: życie, zdrowie, godność, swoboda sumienia, wizerunek, nie dają się postrzegać jako dobra osobiste przysługujące osobie prawnej ${ }^{7}$. W doktrynie prawa cywilnego podkreśla się, że zarówno literatura, jak i orzecznictwo zachowują dużą wstrzemięźliwość w „odkrywaniu” nowych dóbr osobistych osób prawnych ${ }^{8}$. Dodatkowo można przyjąć tezę, że specyfika konkretnej osoby prawnej może pozwolić na skonstruowanie innych niż powyższe dóbr osobistych - przykładem jest tutaj uczelnia publiczna, o czym będzie mowa w dalszej części niniejszych rozważań.

Kontynuując podjętą problematykę, należy podkreślić, że w związku z uznaniem przez ustawodawcę $\mathrm{w}$ art. 33 k.c. osób prawnych za podmioty prawa powstała potrzeba przyznania tym podmiotom odpowiednich instrumentów w celu zapewnienia im należytej ochrony prawnej. Ochrona ta, co jest w pełni uzasadnione, przejawia się poprzez zabezpieczenie interesów, zarówno o charakterze majątkowym, jak i na płaszczyźnie niemajątkowej, czyli dóbr osobistych. W literaturze przedmiotu podkreśla się, że przepisy Kodeksu cywilnego stanowią wystarczającą podstawę skutecznej ochrony osób prawnych w zakresie dóbr osobistych. Ze względu jednak na ich ogólne sformułowanie ciężar ich adekwatnego stoso-

3 Por. wyrok SN z dnia 14 listopada 1986 r., II CR 295/86, OSNCP 1988, nr 2-3, poz. 40; M. Pazdan, [w:] Kodeks cywilny, t. 1: Komentarz do art. 1-449 ${ }^{10}$, red. K. Pietrzykowski, Legalis 2018, art. 43, Nb 4; G. Gorczyński, [w:] Kodeks cywilny. Komentarz, t. 1: Część ogólna (art. 1-125), red. M. Fras, M. Habdas, Legalis 2018, art. 43, Nb 5.

4 Wyrok SN z dnia 11 sierpnia 2016 r., I CSK 419/15, Legalis nr 1507540.

5 Zob. G. Gorczyński, op. cit., art. 43, Nb 20.

6 Zob. szerzej: wyrok SA w Katowicach z dnia 25 lutego 2014 r. (V ACa 690/13, Legalis nr 831368), w którym Sąd opowiedział się przeciwko przypisaniu osobom prawnym dobra osobistego w postaci prywatności.

7 Por. wyrok SN z dnia 5 kwietnia 2013 r., III CSK 198/12, OSNC 2013, nr 12, poz. 141.

8 A. Wolter, J. Ignatowicz, K. Stefaniuk, Prawo cywilne. Zarys części ogólnej, Warszawa 2018, s. 257. 
wania spoczywa na sądach ${ }^{9}$. W związku z powyższym osoba prawna, poszukując w konkretnym stanie faktycznym ochrony swoich dóbr osobistych, w pierwszej kolejności musi wykazać, że naruszone zostało prawo podmiotowe, którego przedmiotem jest określone dobro osobiste ${ }^{10}$. Jednakże sądy, rozpoznając daną sprawę, mają także za zadanie ustalenie, z jakim dobrem osobistym wiąże się ewentualne naruszenie dóbr osobistych, a więc czy zostało ono prawidłowo wskazane przez uprawnionego, oraz stwierdzenie, czy dane dobro podlega ochronie prawnej jako dobro osobiste. Sądy, rozstrzygając sprawy z zakresu dóbr osobistych osób prawnych, kierują się zaaprobowaną w literaturze zasadą, iż do ustalenia wartości niemajątkowych chronionych jako dobra osobiste osób prawnych oraz do oceny ich naruszenia nie wchodzą w rachubę kryteria subiektywne, lecz wyłącznie obiektywne ${ }^{11}$. Przyjęcie takiego rozwiązania oznacza, że to oceny społeczne, a nie wewnętrzne odczucia, decydują o wyróżnieniu poszczególnych dóbr osobistych osób prawnych oraz przesądzają, czy nastąpiło ich naruszenie. Uchyla to konieczność odwoływania się do ujemnych przeżyć psychicznych, jakich z natury rzeczy nie mogą doznawać osoby prawne ${ }^{12}$.

Podsumowując tę część wywodów, należy wskazać, że zawsze punktem wyjścia do rozważań o dobrach osobistych osób prawnych winno się czynić kwestie związane z dobrami osobistymi przysługującymi osobom fizycznym. Pomimo tego, że nie jest możliwe dosłowne odniesienie definicji dóbr osobistych stworzonej na potrzeby osób fizycznych do osób prawnych, to w polskim prawie cywilnym występuje jednolita koncepcja dóbr osobistych ${ }^{13}$. Przyjęcie powyższej konstatacji determinuje uznanie, że „odkrywanie” nowych dóbr osobistych osób prawnych, a także rozstrzyganie indywidualnych sporów przez sądy z tego zakresu nie może być zawieszone w próżni. Należy bowiem, uwzględniając odmienną naturę osób prawnych, przestrzegać nakazu odpowiedniego stosowania przepisów o ochronie dóbr osobistych osób fizycznych do osób prawnych wyrażonego w art. 43 k.c.

9 A. Kubiak-Cyrul, Ochrona dóbr osobistych osób prawnych w prawie polskim, [w:] Dobra osobiste w XXI wieku. Nowe wartości, zasady, technologie, red. J. Balcarczyk, Warszawa 2012, s. $486-487$.

${ }_{10}$ Zob. J. Frąckowiak, [w:] System Prawa Prywatnego, t. 1: Prawo cywilne - część ogólna, red. M. Safjan, Warszawa 2012, s. 1199.

11 A. Wolter, J. Ignatowicz, K. Stefaniuk, op. cit., s. 256.

12 A Szpunar, op. cit., s. 30.

${ }^{13}$ E. Marcisz, Dobra osobiste osób prawnych - uwagi na temat wyktadni art. $43 \mathrm{KC}$, ,Monitor Prawniczy" 2011, nr 13, s. 711. 
II.

Postępujący rozwój zainteresowania problematyką dóbr osobistych osób prawnych zbiegł się w czasie z przeprowadzoną niedawno reformą szkolnictwa wyższego. Sejm Rzeczypospolitej dnia 20 lipca 2018 r. uchwalił nową ustawę Prawo o szkolnictwie wyższym i nauce ${ }^{14}$, która zastąpiła dotychczas obowiązującą ustawę z dnia 27 lipca 2005 r. - Prawo o szkolnictwie wyższym. Nowa ustawa wprowadziła także zmiany w podstawowych definicjach legalnych. Jedna z nich polega na modyfikacji pojęcia uczelni publicznej. Uwzględniając kryterium podmiotu kreującego, uczelnie dzieli się obecnie na publiczne i niepubliczne ${ }^{15}$. Ponadto art. 13 ust. 2 p.s.w. wyodrębnia inny podział uczelni - na akademickie oraz zawodowe. Uczelnia publiczna, w świetle art. 13 ust. 1 p.s.w., to taka uczelnia, która tworzona jest przez organ państwa. Zgodnie z art. 35 ust. 1 p.s.w. publiczną uczelnię akademicką tworzy się w drodze ustawy - oznacza to, że właściwym organem państwowym do jej powołania jest Sejm RP. Natomiast publiczną uczelnię zawodową, zgodnie z art. 35 ust. 2 p.s.w., tworzy się w drodze rozporządzenia ministra właściwego ds. szkolnictwa wyższego i nauki.

Należy w związku z tym przyjąć, że uczelnia publiczna utworzona zostaje w momencie wejścia w życie właściwej ustawy lub rozporządzenia. $\mathrm{Z}$ tą chwilą uzyskuje też osobowość prawną, która przysługuje jej z mocy art. 9 p.s.w., i staje się podmiotem prawa cywilnego - osobą prawną. Szczegółowe zasady dotyczące łączenia uczelni, instytutów badawczych czy instytutów PAN, czego konsekwencją jest powstanie nowej uczelni publicznej, określa art. 35 ust. 3-11 p.s.w. Zgodnie z art. 36 p.s.w. uczelnia traci osobowość prawną z dniem ogłoszenia przez ministra w Monitorze Sądowym i Gospodarczym o zakończeniu likwidacji.

III.

W świetle dotychczasowych ustaleń nie budzi wątpliwości fakt, że uczelni publicznej, jako osobie prawnej, przysługują dobra osobiste, które podlegają ochronie na podstawie przepisów Kodeksu cywilnego. Warto przytoczyć trafny pogląd wyrażony przez Sąd Najwyższy, zgodnie z którym szkoła wyższa może należycie wypełniać powierzone jej zadania dydaktyczno-wychowawcze, polegające na kształceniu i wychowywaniu młodzieży, tylko wówczas, gdy dysponuje odpowiednio wysokim autorytetem wychowawczym i moralnym ${ }^{16}$. W dalszej

${ }^{14}$ Ustawa z dnia 20 lipca 2018 r. - Prawo o szkolnictwie wyższym i nauce (t.j. Dz.U. 2019, poz. 276 ze zm.), dalej: p.s.w.

${ }^{15}$ M. Rutkowska-Sowa, [w:] Komercjalizacja i transfer wyników badań naukowych i prac rozwojowych z uczelni do gospodarki. Komentarz - nowe regulacje, red. J. Sieńczyło-Chlabicz, Legalis 2019.

16 Wyrok SN z dnia 14 listopada 1986 r., II CR 295/86, OSNCP 1988, nr 2-3, poz. 40. 
części rozważań należy zastanowić się, jakie dobra osobiste przysługują uczelni publicznej i co za tym idzie podlegają ochronie za pomocą środków przewidzianych w Kodeksie cywilnym.

W pierwszej kolejności należy zwrócić uwagę na dobro osobiste osób prawnych, jakim jest nazwa. Nazwa publicznej uczelni akademickiej ustanawiana jest w ustawie o jej utworzeniu, a publicznej uczelni zawodowej - we właściwym rozporządzeniu. Zmiana nazwy wymaga odpowiednio zmiany ustawy lub wydania nowego rozporządzenia. Nazwa osoby prawnej jest odpowiednikiem nazwiska osoby fizycznej. Pozwala ona odróżnić dany podmiot od innego - służy do jego indywidualizacji ${ }^{17}$. Naruszenie prawa do nazwy może polegać na tym, że nazwa lub jej część, z której brzmieniem jest kojarzona dana osoba prawna, zostanie użyta w treści nazwy innej osoby prawnej, powodując ryzyko błędnej identyfikacji ${ }^{18}$. Można bowiem wyobrazić sobie sytuację, że na określonym obszarze, w obrębie którego funkcjonuje określona uczelnia publiczna o wysokim prestiżu, powstaje inny podmiot prywatny świadczący usługi w zakresie kształcenia wyższego lub policealnego o identycznej lub zbliżonej nazwie do nazwy uczelni publicznej. W takim wypadku można uznać, że dochodzi do naruszenia dobra osobistego w postaci nazwy.

W przypadku osób prawnych, w tym szczególnie uczelni publicznych, można mówić o charakterystycznych dobrach osobistych związanych z ich identyfikacją, innych niż jej nazwa. Chodzi konkretnie o symbole uczelni wyższej, które każdorazowo ustalane są w aktach o charakterze wewnętrznym, najczęściej w statucie. Takimi symbolami są przede wszystkim: herb, logo, sztandar, flaga oraz pieczęć ${ }^{19}$ - nie jest to jednak katalog zamknięty ani wyczerpujący. Symbole pełnią funkcję indywidualizującą uczelnię, ponieważ są bardzo często nośnikiem jej tożsamości w zewnętrznym odbiorze. W polskim systemie

17 Por. L.K. Jaskuła, Prawo do dobrego imienia a wolność prasy, Warszawa 2009, s. 169 i n.

18 Por. wyrok SN z dnia 28 października 1998 r., II CKN 25/98, OSN 1999, nr 4, poz. 80.

19 W prawie polskim nie występują definicje legalne powyższych pojęć, oprócz definicji pieczęci urzędowej. Zgodnie z art. 2a pkt 12 ustawy z dnia 31 stycznia 1980 r. o godle, barwach i hymnie Rzeczypospolitej Polskiej oraz o pieczęciach państwowych (t.j. Dz.U. 2019, poz. 1509 ze zm.) uczelnie publiczne mają prawo do posługiwania się pieczęcią urzędową. Art. 6c ust. 1 powyższej ustawy definiuje pieczęć urzędową jako metalową, tłoczoną pieczęć, okrągłą, zawierającą pośrodku wizerunek orła ustalony dla godła Rzeczypospolitej Polskiej, posiadającą w otoku napis odpowiadający nazwie podmiotu uprawnionego do używania urzędowej pieczęci. Pozostałe symbole uczelni publicznej należy rozumieć tak samo, jak w języku powszechnym. Oznacza to, że herb - pierwszy ze wskazanych symboli - można zdefiniować jako zaszczytny znak graficzny uczelni, składający się z godła umieszczonego na tarczy z zastosowaniem odpowiedniego barwienia, odnoszący się symbolicznie do historii i tradycji pielęgnowanych przez daną uczelnię. Mniej formalnym od herbu symbolem uczelni publicznej jest logo, które można określić jako charakteryzującą uczelnię formę graficzną, napis lub inną formę ekspresji graficznej, która służy w celach identyfikacyjnych . Kolejnym symbolem uczelni publicznej jest sztandar, czyli chorągiew, często z wyhaftowanym godłem lub hasłem. Ostatnim wskazanym symbolem uczelni jest flaga, czyli choragiew w barwach charakterystycznych dla danej uczelni. 
prawnym nie występuje definicja legalna symbolu, w związku z czym należy go rozumieć tak samo, jak w języku powszechnym ${ }^{20}$. Sąd Najwyższy stwierdził, że oznaczenie symbolizujące określoną osobę prawną (zwłaszcza graficzne) może zostać zaliczone do dóbr osobistych podlegających ochronie, nawet jeżeli nie wyraża całości albo części nazwy osoby prawnej. Sąd uznał więc, że kryterium zewnętrznego postrzegania uzasadnia sformułowanie wniosku o istnieniu dobra osobistego osoby prawnej w postaci znaku ją symbolizującego. Rozstrzygając konkretny stan faktyczny dotyczący dóbr osobistych uczelni publicznej, Sąd Najwyższy wskazał, iż znak orła będący elementem godła uniwersytetu, stanowiący wraz z elementami ornamentyki koronę bramy wejściowej do siedziby uniwersytetu, jest charakterystyczny tylko dla danej uczelni oraz symbolizuje wartości naukowe, dydaktyczne i moralne w dorobku historycznym i bieżących osiągnięciach kadry naukowej i wychowanków uniwersytetu. Sąd podkreślił, że znak orła uosabia uniwersytet, wyraża jego tożsamość i znaczenie. Jako element wizerunku uniwersytetu powinien być wykorzystywany w celach zgodnych z symboliką, jaką reprezentuje, i bez zgody uniwersytetu nie może być wykorzystywany ${ }^{21}$. W związku z powyższym słusznie uznano, że używanie przez osoby trzecie charakterystycznych elementów architektonicznych uniwersytetu, do których należy brama uczelni z godłem uczelni, będąca częścią zewnętrznego wizerunku uniwersytetu, bez zgody władz uczelni jest naruszeniem wizerunku tej uczelni, a tym samym narusza jej dobra osobiste ${ }^{22}$. Zgodnie ze wskazanymi ustaleniami sądu należy zaaprobować tezę, że używanie przez podmioty nieuprawnione jakichkolwiek oznaczeń stanowiących symbole uczelni publicznej jest podstawą do wystąpienia $\mathrm{z}$ roszczeniami przewidzianymi w Kodeksie cywilnym przeciwko ich naruszycielowi.

Kolejnym dobrem osobistym, które przypisuje się osobom prawnym, jest dobre imię. Jak podkreślił Sąd Najwyższy, do naruszenia dobra osobistego osoby prawnej, w szczególności jej prawa do dobrego imienia (dobrej sławy, reputacji), dochodzi dopiero wówczas, gdy zachowanie sprawcy prowadzi (lub potencjalnie może prowadzić) do utraty zaufania do niej, potrzebnego do prawidłowego funkcjonowania w zakresie jej zadań ${ }^{23}$. Nie budzi wątpliwości, że wskazane dobro osobiste przysługuje także uczelniom publicznym. Jak już zostało wskazane, uczelnia publiczna ze względu na swoją misję w postaci kształcenia studentów oraz rozwoju badań naukowych musi cieszyć się w społeczeństwie wysokim autorytetem. Bez niego, przy dużej liczbie pozostałych podmiotów kształcących na

${ }^{20}$ Symbolem jest pojęcie, wyobrażenie, znak, przedmiot kojarzący się z innym pojęciem, wyobrażeniem, znakiem, przedmiotem, pełniący funkcję zastępczą wobec jakiegoś zjawiska - Wielki stownik języka polskiego, red. B. Dunaj, Warszawa 2011, s. 667.

${ }^{21}$ Wyrok SN z dnia 7 marca 2003 r., I CKN 100/01, Legalis nr 58171.

22 Wyrok SA w Warszawie z dnia 29 maja 2000 r., I ACa 1617/99, LEX nr 49243.

${ }^{23}$ Wyrok SN z dnia 11 stycznia 2007 r., II CSK 392/06, OSP 2009, nr 5, poz. 55. 
studiach wyższych, uczelnia mogłaby stać się nieatrakcyjna dla kandydatów na studia, a wyniki badań naukowych przez nią prowadzone mogłyby być w naukowym środowisku deprecjonowane.

W literaturze przedmiotu wskazuje się, że dobre imię osoby prawnej może zostać naruszone w trzech sytuacjach ${ }^{24}$. Może to polegać na rozpowszechnianiu nieprawdziwych informacji o podmiocie, które podważają jego reputację. Tytułem przykładu naruszenia w taki sposób dobrego imienia uczelni publicznej można wskazać hipotetyczną sytuację, w której prasa czy też inne środki masowego przekazu podczas trwającej rekrutacji rozpowszechniają niezgodne z prawdą informacje o niskim poziomie kształcenia na danej uczelni publicznej, co w konsekwencji prowadzi do zmniejszenia naboru i utraty przez uczelnię nie tylko prestiżu, lecz także środków finansowych. Drugim przypadkiem, w którym dochodzi do naruszenia dobrego imienia osoby prawnej, jest rozpowszechnianie wypowiedzi wartościujących, poddających podmiot krytyce, nieznajdujących jednak oparcia w faktach. Trzecia sytuacja, wskazana w doktrynie, dotyczy szczególnego przypadku, gdy „opublikowanie prawdziwej informacji o podmiocie może stanowić naruszenie dobrego imienia” ze względu na „kontekst sytuacyjny i społeczny odbiór takiej informacji”25. Podkreślić wszakże należy, że uznanie takiej sytuacji jako przykład w rozpatrywanej tu kwestii powinno mieć charakter wyjątkowy, ponieważ zasadą jest, że rozpowszechnianie informacji zgodnych z prawdą wyłącza bezprawność naruszenia dobra osobistego ${ }^{26}$. Dostrzegł to również Sąd Najwyższy, wskazując, że w takim kontekście niezbędne jest uwzględnianie nie tylko semantycznego znaczenia użytych słów, ale też kontekstu sytuacyjnego i społecznego oraz konieczności oceny odbioru według kryteriów właściwych dla ludzi rozsądnych i uczciwych ${ }^{27}$.

Dobre imię może zostać naruszone w sytuacji, kiedy adresatem rozpowszechnianych nieprawdziwych lub nieznajdujących oparcia w faktach, wartościujących informacji jest bezpośrednio sama osoba prawna ujmowana w sposób abstrakcyjny. Należy podkreślić, że w orzecznictwie aprobowany jest także pogląd, iż negatywne wypowiedzi na temat osób wchodzących w skład organów osoby prawnej mogą również prowadzić do naruszenia jej dobrego imienia ${ }^{28}$. Organami uczelni publicznej, zgodnie z art. 17 ust. 1 p.s.w., są rada uczelni, rektor i senat. Przepis art. 17 ust. 2 p.s.w. ponadto wskazuje, że statut uczelni może przewidywać inne organy uczelni. Należy uznać, że skoro osoba prawna (w tym uczelnia publiczna)

${ }^{24}$ K. Michałowska, Dobre imię osoby prawnej w świetle orzecznictwa, „Studia Oeconomica Posnaniensia" 2015, nr 3, s. 14.

25 Ibidem.

26 Zob. wyrok SA w Warszawie z dnia 5 lutego 2014 r., I ACa 1520/13, Legalis nr 797483.

27 Zob. wyrok SN z dnia 23 maja 2002 r., IV CKN 1076/00, Legalis nr 55858.

${ }^{28}$ Zob. np. wyrok SA w Krakowie z dnia 28 września 1994 r., I ACa 464/99, TPP 2000, nr 3, s. 131; wyrok SN z dnia 10 listopada 2005 r., V CK 314/05, LEX nr 186727. 
działa przez swoje organy, to zarzuty kierowane wobec osób piastujących funkcje organów jednoosobowych lub wchodzących w skład organów kolegialnych uczelni mogą być jednocześnie zarzutami kierowanymi pod adresem samej uczel$\mathrm{ni}^{29} \mathrm{i}$ stanowić naruszenie jej dóbr osobistych. Konieczne jest w takim przypadku istnienie wyraźnego związku pomiędzy działalnością takich osób i funkcjonowaniem danej uczelni.

W kontekście powyższych rozważań warto przytoczyć inny pogląd występujący w orzecznictwie, według którego negatywne wypowiedzi na temat nie tylko osób wchodzących w skład organów osoby prawnej, lecz także jej pracowników mogą prowadzić do naruszenia dobrego imienia samej osoby prawnej. W ramach tej opcji Sąd Apelacyjny w Warszawie w wyroku z dnia 2 lutego $2011 \mathrm{r}^{30}$ wytyczył szeroki krąg adresatów wypowiedzi naruszającej dobre imię osoby prawnej, ponieważ nie ograniczył się wyłącznie do osób wchodzących w skład jej organów, lecz także wskazał na pracowników osoby prawnej. W przypadku uczelni publicznej jej pracownikami są zarówno nauczyciele akademiccy, jak i pracownicy administracyjni. Uznając specyfikę osoby prawnej, jaką jest uczelnia publiczna, należy przyjąć, iż negatywne lub wartościujące wypowiedzi względem osób fizycznych powiązanych z uczelnią, a niepełniących funkcji organów tej osoby prawnej, mogą stanowić naruszenie dóbr osobistych samej uczelni. W takich przypadkach należy jednak indywidualnie badać tak rodzaj wypowiedzi, jak i charakter powiązania z uczelnią osób, których dotyczy określona wypowiedź.

Innymi dobrami osobistymi osób prawnych są tajemnica korespondencji oraz nietykalność pomieszczeń. W odniesieniu do pierwszego z nich należy wskazać, że jest ono dobrem osobistym przysługującym osobom prawnym na takich samych zasadach, jak osobie fizycznej ${ }^{31}$. Istota tego dobra osobistego polega na tym, że niedopuszczalne jest przekazywanie korespondencji osobom nieuprawnionym, przeglądanie jej przez takie osoby, korzystanie z zawartych w niej informacji czy zniekształcanie jej treści. W przypadku uczelni publicznych, które najczęściej mają bardzo złożoną wewnętrzną strukturę organizacyjną, należy przyjąć, że naruszenie tajemnicy korespondencji może nastąpić zarówno poprzez dokonywanie wymienionych czynności w stosunku do korespondencji kierowanej do uczelni przez zewnętrzne podmioty, jak i w odniesieniu do korespondencji wewnętrznej, przekazywanej między jej pracownikami lub jednostkami organizacyjnymi.

${ }_{29}$ Zob. szerzej na temat naruszenia dobrego imienia osoby prawnej w kontekście adresatów informacji naruszających dobra osobiste: K. Riedl, Naruszenie dobrego imienia osoby prawnej poprzez wypowiedzi dotyczace powiązanych z niq osób fizycznych, „Przegląd Prawniczy Uniwersytetu Warszawskiego" 2017, nr 1, s. 141 i n.

${ }^{30}$ I ACa 909/10, LEX nr 1120187.

31 Por. P. Księżak, [w:] Kodeks cywilny. Część ogólna, red. M. Pyziak-Szafnicka, Warszawa 2009, s. 396. 
Drugie ze wskazanych dóbr - nietykalność pomieszczeń - jest wzorowane na nietykalności mieszkania osoby fizycznej. W literaturze w odniesieniu do tego dobra osobistego występują dwa poglądy. Pierwszy z nich, prezentowany m.in. przez E. Gniewka, wskazuje, że ochronie podlegać powinny jedynie pomieszczenia zajmowane przez organy osoby prawnej i ich personel, a nie wszystkie budynki należące do osoby prawnej ${ }^{32}$. Drugi pogląd, sformułowany przez J. Frąckowiaka, opowiada się za szerszym ujęciem zakresu ochrony pomieszczeń i rozciągnięciem jej na te pomieszczenia, w których osoba prawna prowadzi działalność, wypełniając swoje statutowe funkcje ${ }^{33}$. Ze względu na specyfikę osoby prawnej, jaką jest uczelnia publiczna, a także prowadzonej przez nią działalności badawczo-dydaktycznej należy opowiedzieć się za drugim z prezentowanych poglądów. Wydaje się, że ochronie podlegają nie tylko pomieszczenia zajmowane przez organy osoby prawnej (tj. rektora, senat i radę uczelni), lecz także sale wykładowe i ćwiczeniowe oraz pokoje pracowników naukowych i administracyjnych.

IV.

Zasadą przyjętą na gruncie przepisów Kodeksu cywilnego jest, że w razie zagrożenia lub naruszenia dóbr osobistych osobie prawnej przysługują takie same środki ochrony, jak osobom fizycznym. Przesłankami ochrony są zagrożenie lub naruszenie dobra osobistego oraz bezprawność takiego działania. Jednak to na naruszającym dobra osobiste spoczywa ciężar dowodu, że jego zachowanie nie było bezprawne. W literaturze za bezsporne okoliczności wyłączające bezprawność uznaje się zgodę uprawnionego, działanie w ramach obowiązującego porządku prawnego oraz wykonywanie prawa podmiotowego ${ }^{34}$.

Pierwszą ze wskazanych okoliczności wyłączających bezprawność naruszenia dobra osobistego jest zgoda uprawnionego. W literaturze przedmiotu wskazuje się, że istota powyższego kontratypu jest związana z konstrukcją prawa

${ }^{32}$ E. Gniewek, [w:] Kodeks cywilny. Komentarz, red. E. Gniewek, P. Machnikowski, Legalis 2019, art. 43, Nb 4.

33 J. Frąckowiak, op. cit., s. 1096-1097.

${ }^{34}$ Zob. J. Panowicz-Lipska, [w:] Kodeks cywilny, t. 1: Komentarz do art. 1-352, red. M. Gutowski, Legalis 2018, art. 24, Nb 9; J. Regan, [w:] Kodeks cywilny. Komentarz, red. M. Załucki, Legalis 2019, art. 24, Nb 3. W orzecznictwie i w literaturze istnieje spór, czy działanie w obronie uzasadnionego interesu społecznego lub prywatnego także może stanowić okoliczność wyłączającą bezprawność naruszenia dobra osobistego. Zob. szerzej argumenty: aprobujące powyższe twierdzenie, np. wyrok SN z dnia 29 października 1971 r., II CR 455/71, OSN 1972, nr 4, poz. 77; wyrok SN z dnia 14 listopada 1986 r., II CR 295/86, OSNCP 1988, nr 2-3, poz. 40; nieuznające powyższej okoliczności za wyłączającą bezprawność, np. E. Łętowska, K. Osajda, [w:] System Prawa Prywatnego, t. 1: Prawo cywilne..., s. 1279-1280. 
podmiotowego, która zakłada swobodę korzystania z niego ${ }^{35}$. Charakteryzowana zgoda: po pierwsze, powinna wskazywać dokładnie dobro osobiste, które może zostać naruszone; po drugie, może dotyczyć wyłącznie dobra tej osoby, która zgody udziela ${ }^{36}$; po trzecie, nie może być sprzeczna z normami prawnymi i zasadami współżycia społecznego. Udzielona zgoda jest skuteczna, jeżeli została wyrażona przez osobę uprawnioną, zarówno przed spowodowaniem zagrożenia lub naruszenia dobra osobistego, jak i w chwili dokonywania naruszenia dobra. Należy jednak podkreślić, że może ona zostać w każdej chwili cofnięta, również podczas już trwających działań naruszających.

Drugą okolicznością wyłączającą bezprawność jest tzw. działanie w ramach obowiązującego porządku prawnego. Zgodnie z utrwalonym poglądem głoszonym w literaturze ustalenie tej okoliczności wymaga stwierdzenia, że obowiązuje określona norma prawna upoważniająca wskazany podmiot do naruszenia dobra osobistego innego podmiotu ${ }^{37}$. Jeśli taka norma istnieje, to określone zachowanie, które byłoby uznane za naruszające dobro osobiste, staje się działaniem zgodnym z prawem. Z zakresu prawa cywilnego można, jako przykłady takich unormowań, wskazać instytucję obrony koniecznej (art. 423 k.c.) czy dozwolonej samopomocy (art. $343 \S 2$ k.c.).

Trzecią okolicznością wyłączającą bezprawność naruszenia dobra osobistego jest wykonywanie prawa podmiotowego. Wykonywanie prawa podmiotowego należy odróżnić od działania na podstawie przepisu prawnego, ponieważ osoba działająca na podstawie prawa nigdy nie działa bezprawnie, natomiast działanie, które pozornie stanowi wykonywanie prawa podmiotowego, może zostać uznane za bezprawne, jeśli jest sprzeczne z zasadami współżycia społecznego ${ }^{38}$. Aby doszło do wyłączenia bezprawności na podstawie powyższego kontratypu, prawo podmiotowe przysługujące i wykonywane przez sprawcę naruszenia - wynikające z przepisów ustawy lub treści czynności prawnej - musi być skuteczne wobec osoby, której dobro osobiste doznaje uszczerbku. Ponadto wykonujący swoje prawo podmiotowe nie może go nadużywać w rozumieniu art. 5 k.c.

$\mathrm{W}$ razie bezprawnego naruszenia lub zagrożenia dobra osobistego uprawnionemu przysługują środki ochrony o charakterze majątkowym lub niemajątkowym $^{39}$. Z żądaniem ochrony może występować każda osoba, w tym osoba prawna, która została bezpośrednio dotknięta naruszeniem. Do niemajątkowych środków ochrony dóbr osobistych zalicza się, zgodnie z art. $24 \S 1$ k.c., roszczenie o zaniechanie w przypadku zagrożenia naruszenia dobra osobistego. Po

${ }^{35}$ Zob. Z. Radwański, Koncepcja praw podmiotowych osobistych, „Ruch Prawniczy, Ekonomiczny i Socjologiczny" 1988, nr 2, s. 13.

36 Zob. szerzej: E. Łętowska, K. Osajda, op. cit., s. 1274-1275.

37 Zob. J. Panowicz-Lipska, op. cit., art. 24, Nb 11.

38 Wyrok SN z dnia 15 kwietnia 2004 r., IV CK 284/03, Legalis nr 73102.

39 Zob. A. Wolter, J. Ignatowicz, K. Stefaniuk, op. cit., s. 256. 
dokonaniu naruszenia uprawnionemu, oprócz roszczenia o zaniechanie, przysługuje także roszczenie o usunięcie jego skutków, w szczególności poprzez złożenie oświadczenia o odpowiedniej treści i w odpowiedniej formie. Ponadto na podstawie art. 189 Kodeksu postępowania cywilnego ${ }^{40}$ przysługuje mu powództwo o ustalenie istnienia lub nieistnienia prawa lub stosunku prawnego.

Pierwsze z powyższych roszczeń - roszczenie o zaniechanie - jest jedynym, z którego podmiot uprawniony może skorzystać zarówno przed dokonanym naruszeniem dobra osobistego, jak i po jego naruszeniu. Podstawową przesłanką uprawniającą do wystąpienia z powyższym roszczeniem jest istnienie stanu zagrożenia w postaci obiektywnego i uzasadnionego przekonania, że naruszenie konkretnego dobra osobistego jest prawdopodobne w przyszłości ${ }^{41}$. Przekonanie to może istnieć zarówno w sytuacji, gdy dobro osobiste nie zostało jeszcze naruszone, jak i w przypadku, gdy do naruszenia dobra osobistego już doszło, ale zachodzi realne prawdopodobieństwo, że bezprawne działania będą kontynuowane. W obu powyższych sytuacjach roszczenie o zaniechanie ma charakter prewencyjny - ma zapobiegać naruszaniu dobra osobistego w przyszłości. Dochodząc tego roszczenia, uprawniony musi wskazać, jakiego konkretnego zachowania ${ }^{42}$ (czynnego lub biernego) domaga się od osoby, ze strony której grozi mu naruszenie.

Drugim roszczeniem o charakterze niemajątkowym - zgodnie z art. 24 $\S 1$ k.c. - jest roszczenie o usunięcie skutków dokonanego naruszenia, w szczególności poprzez złożenie oświadczenia o odpowiedniej treści i w odpowiedniej formie. W przeciwieństwie do roszczenia o zaniechanie $\mathrm{z}$ powyższym roszczeniem można wystąpić wyłącznie po dokonanym już naruszeniu dobra osobistego. Ustawodawca w tym artykule wskazuje, że podmiot uprawniony może żądać od naruszyciela dopełnienia czynności potrzebnych do usunięcia skutków naruszenia, a jako przykład takiego działania wskazuje zachowanie polegające na złożeniu oświadczenia o odpowiedniej treści i w odpowiedniej formie. Wskazany sposób zachowania jednak w sposób oczywisty nie wyklucza innych form usunięcia skutków naruszenia. Zgodnie z poglądem wyrażonym w orzecznictwie powinny być to takie czynności, które w konkretnym stanie faktycznym, zgodnie z powszechnie przyjętymi poglądami i opiniami danego środowiska, będą stanowiły ekwiwalent wyrządzonej krzywdy, jednocześnie niwelując jej skutki³ ${ }^{43}$ Mogą one polegać na sprostowaniu nieprawdziwych informacji, ubolewaniu czy przeprosinach - nie jest to katalog zamknięty. Zgodnie z poglądami wyrażanymi w literaturze czynności podejmowane przez sprawcę naruszenia powinny przynieść

${ }^{40}$ Ustawa z dnia 17 listopada 1964 r. - Kodeks postępowania cywilnego (t.j. Dz.U. 2019, poz. 1460 ze zm.), dalej: k.p.c.

${ }^{41}$ P. Machnikowski, [w:] Kodeks cywilny. Komentarz, red. E. Gniewek, P. Machnikowski, Legalis 2019, art. 24, $\mathrm{Nb} 14$.

${ }^{42}$ Por. wyrok SN z dnia 9 lipca 1971 r., II CR 220/71, OSNCP 1972, nr 1, poz. 19.

${ }^{43}$ Uchwała SN z dnia 29 grudnia 1971 r., III CZP 87/71, OSNCP 1972, nr 6, poz. 104. 
satysfakcję osobie, której dobra osobiste zostały naruszone oraz przeciwdziałać podobnym naruszeniom w przyszłości, a więc spełniać funkcję prewencyjno-wychowawczą ${ }^{44}$. Dochodząc usunięcia skutków naruszenia poprzez wydanie określonego oświadczenia, uprawniony powinien wyraźnie sformułować jego treść w pozwie ${ }^{45}$, a sąd jest obowiązany do zamieszczenia tego oświadczenia $\mathrm{w}$ sentencji wyroku ${ }^{46}$.

Trzecim środkiem ochrony niemajątkowej dóbr osobistych jest powództwo o ustalenie istnienia prawa lub stosunku prawnego ${ }^{47}$. Zgodnie $\mathrm{z}$ art. 189 k.p.c. powód może żądać ustalenia przez sąd istnienia lub nieistnienia stosunku prawnego lub prawa, gdy ma w tym interes prawny. W związku z powyższym jedyną przesłanką wytoczenia powyższego powództwa jest posiadanie przez uprawnionego interesu prawnego. Do przyjęcia, że interes prawny istnieje po stronie uprawnionego, wystarczy wskazanie, że wyrok usunie mającą charakter obiektywny niepewność stanu prawnego ${ }^{48}$. Samo stwierdzenie, że uprawnionemu przysługuje dane dobro osobiste, może bowiem skutecznie przeciwdziałać jego naruszaniu w przyszłości.

Środkami ochrony majątkowej dóbr osobistych są roszczenie o odszkodowanie oraz roszczenie o zadośćuczynienie pieniężne lub zapłatę odpowiedniej sumy na wskazany cel społeczny. Pierwsze z roszczeń majątkowych - roszczenie odszkodowawcze - przysługuje osobom prawnym, jeżeli wskutek naruszenia dobra osobistego została wyrządzona szkoda majątkowa. W takiej sytuacji, zgodnie z art. $24 \S 2$ k.c., poszkodowany może żądać jej naprawienia na zasadach ogólnych. Dochodząc powyższego roszczenia, uprawniony jest obowiązany nie tylko do wskazania, że zaszły przesłanki naruszania jego dóbr osobistych z art. 24 $\S 1$ k.c., lecz także musi wykazać spełnienie przesłanek, od których zależy odpowiedzialność odszkodowawcza ${ }^{49}$.

Podstawą prawną drugiego z przytoczonych wyżej roszczeń majątkowych jest art. $24 \S 1$ zdanie trzecie, zgodnie z którym ten, czyje dobro osobiste zostało naruszone, może żądać - na zasadach przewidzianych w Kodeksie cywilnym - zadośćuczynienia pieniężnego lub zapłaty odpowiedniej sumy pieniężnej na wskazany cel społeczny. Przepis ten odsyła więc do art. 445 i 448 k.c. Zgodnie z poglądami powszechnie akceptowanymi w literaturze, $\mathrm{z}$ uwagi na charakter naruszonych dóbr osobistych wskazanych w art. 445 k.c. (uszkodzenia ciała, wywołanie rozstroju zdrowia, pozbawienie wolności, skłonienie za pomocą podstępu, gwałtu lub nadużycia stosunku zależności do poddania się czynowi nierządne-

\footnotetext{
${ }^{44}$ P. Sobolewski, [w:] Kodeks cywilny. Komentarz, red. K. Osajda, Legalis 2019, art. 24, Nb 66.

45 Wyrok SN z dnia 22 grudnia 1997 r., II CKN 546/97, OSNIC 1998, nr 7-8, poz. 19.

46 Wyrok SN z dnia 19 stycznia 1982 r., IV CR 500/81, OSNCP 1982, nr 9-10, poz. 123.

47 Zob. np. wyrok SN z dnia 30 sierpnia 1974 r., I CR 384/74, OSNCP 1977, nr 10, poz. 161; wyrok SN z dnia 22 września 1995 r., III CZP 118/95, OSPiKA 1996, nr 4, poz. 78.

${ }^{48}$ E. Łętowska, K. Osajda, op. cit., s. 1281.

49 Ibidem, s. 1289.
} 
$\mathrm{mu}$, przepis ten znajduje wyłączne zastosowanie do osób fizycznych ${ }^{50}$. Co istotne, w orzecznictwie i literaturze występuje spór dotyczący dopuszczalności zastosowania art. 448 k.c. jako podstawy dla zasądzenia zadośćuczynienia pieniężnego dla osoby prawnej w przypadku naruszenia jej dóbr osobistych ${ }^{51}$. Opowiedzenie się za powyższą koncepcją wymaga uznania, że osoba prawna na skutek naruszenia dóbr osobistych może ponieść uszczerbek o charakterze niemajątkowym, a więc doznać krzywdy. Przeciwko jednak podnoszone jest twierdzenie, iż krzywda stanowi uszczerbek w postaci cierpień fizycznych i psychicznych, które są związane wyłącznie z człowiekiem i nie mogą występować u osób prawnych.

Wymienione środki ochrony dóbr osobistych, zarówno o charakterze majątkowym, jak i niemajątkowym, przysługują w sposób oczywisty uczelniom publicznym w związku z posiadaną przez nie osobowością prawną. Zgodnie z art. 38 k.c. osoba prawna działa przez swoje organy w sposób przewidziany W ustawie i opartym na niej statucie. W przypadku uczelni publicznej przepis art. 23 ust. 2 pkt 1 p.s.w. stanowi, że do zadań rektora należy reprezentowanie uczelni. Oznacza to, że zarówno uczelnię publiczną akademicką, jak i zawodową w stosunkach zewnętrznych reprezentuje rektor. W związku z powyższym osoba pełniąca funkcję rektora ma prawo do dokonywania w imieniu uczelni wszelkich czynności procesowych w postępowaniu sądowym w rozumieniu art. 67 k.p.c. ${ }^{52}$, a więc także w sprawach z zakresu dóbr osobistych.

V.

Konkludując niniejsze rozważania, należy wskazać, że uczelni publicznej przysługują dobra osobiste, które skutecznie może ona chronić za pomocą roszczeń przewidzianych w prawie cywilnym. Może to czynić, działając przez swoje organy zarówno na drodze postępowania sądowego, jak i w sferze pozasądowej. Niewątpliwie do dóbr osobistych uczelni publicznej zalicza się scharakteryzowane wyżej: nazwę, symbole, dobre imię, nietykalność pomieszczeń oraz tajemnicę korespondencji.

Warto podkreślić, że wraz z postępującymi przemianami społecznymi i politycznymi oraz ze zmianą zwyczajów i obyczajów należy się spodziewać dalszego, zasygnalizowanego już na wstępie, „odkrywania”, zarówno w doktrynie, jak i w orzecznictwie, kolejnych dóbr osobistych przysługujących osobom prawnym, w tym uczelniom publicznym.

${ }^{50}$ A. Kubiak-Cyrul, [w:] Kodeks cywilny. Komentarz, red. M. Załucki, Legalis 2019, art. 43, Nb 11.

${ }^{51}$ Zob. argumenty za tym, że osobom prawnym przysługuje opisywane roszczenie, np. wyrok SN z dnia 24 września 2008 r., II CSK 126/08, Legalis nr 118211; uchwała SN z dnia 9 listopada 2017 r., III CZP 43/17, Legalis nr 1682591, a także argumenty przeciw, np. wyrok SA w Krakowie z dnia 28 września 1999 r., I ACa 464/99, Legalis nr 877847; wyrok SO we Wrocławiu z dnia 23 września 2014 r., I C 1765/12, Legalis nr 2170530.

${ }^{52}$ Wyrok SN z dnia 29 czerwca 2011 r., III SK 1/11, Legalis nr 492264. 


\section{BIBLIOGRAFIA}

\section{LITERATURA}

Frąckowiak J., [w:] System Prawa Prywatnego, t. 1: Prawo cywilne - część ogólna, red. M. Safjan, Warszawa 2012.

Gniewek E., [w:] Kodeks cywilny. Komentarz, red. E. Gniewek, P. Machnikowski, Legalis 2019.

Gorczyński G., [w:] Kodeks cywilny. Komentarz, t. 1: Część ogólna (art. 1-125), red. M. Fras, M. Habdas, Legalis 2018.

Jaskuła L.K., Prawo do dobrego imienia a wolność prasy, Warszawa 2009.

Księżak P., [w:] Kodeks cywilny. Czesść ogólna, red. M. Pyziak-Szafnicka, Warszawa 2009.

Kubiak-Cyrul A., [w:] Kodeks cywilny. Komentarz, red. M. Załucki, Legalis 2019.

Kubiak-Cyrul A., Ochrona dóbr osobistych osób prawnych w prawie polskim, [w:] Dobra osobiste w XXI wieku. Nowe wartości, zasady, technologie, red. J. Balcarczyk, Warszawa 2012.

Łętowska E., Osajda K., [w:] System Prawa Prywatnego, t. 1: Prawo cywilne - część ogólna, red. M. Safjan, Warszawa 2012.

Machnikowski P., [w:] Kodeks cywilny. Komentarz, red. E. Gniewek, P. Machnikowski, Legalis 2019.

Marcisz E., Dobra osobiste osób prawnych - uwagi na temat wykładni art. 43 KC, „Monitor Prawniczy" 2011, nr 13.

Michałowska K., Dobre imię osoby prawnej w świetle orzecznictwa, „Studia Oeconomica Posnaniensia" 2015, nr 3.

Panowicz-Lipska J., [w:] Kodeks cywilny, t. 1: Komentarz do art. 1-352, red. M. Gutowski, Legalis 2018.

Pazdan M., [w:] Kodeks cywilny, t. 1: Komentarz do art. 1-44910, red. K. Pietrzykowski, Legalis 2018.

Radwański Z., Koncepcja praw podmiotowych osobistych, „Ruch Prawniczy, Ekonomiczny i Socjologiczny" 1988, nr 2.

Regan J., [w:] Kodeks cywilny. Komentarz, red. M. Załucki, Legalis 2019.

Riedl K., Naruszenie dobrego imienia osoby prawnej poprzez wypowiedzi dotyczace powiazanych z nia osób fizycznych, „Przegląd Prawniczy Uniwersytetu Warszawskiego” 2017, nr 1.

Rutkowska-Sowa M., [w:] Komercjalizacja i transfer wyników badań naukowych i prac rozwojowych z uczelni do gospodarki. Komentarz - nowe regulacje, red. J. Sieńczyło-Chlabicz, Legalis 2019.

Sobolewski P., [w:] Kodeks cywilny. Komentarz, red. K. Osajda, Legalis 2019.

Szpunar A., Ochrona dóbr osobistych przystugujących osobom prawnym, [w:] Problemy kodyfikacji prawa cywilnego. Studia i rozprawy. Ksiega pamiatkowa ku czci Profesora Zbigniewa Radwańskiego, red. S. Sołtysiński, Poznań 1990.

Wielki słownik języka polskiego, red. B. Dunaj, Warszawa 2011.

Wolter A., Ignatowicz J., Stefaniuk K., Prawo cywilne. Zarys części ogólnej, Warszawa 2018.

\section{AKTy PRAWne}

Ustawa z dnia 23 kwietnia 1964 r. - Kodeks cywilny (t.j. Dz.U. 2019, poz. 1460 ze zm.).

Ustawa z dnia 17 listopada 1964 r. - Kodeks postępowania cywilnego (t.j. Dz.U. 2019, poz. 1460 ze zm.).

Ustawa z dnia 31 stycznia 1980 r. o godle, barwach i hymnie Rzeczypospolitej Polskiej oraz o pieczęciach państwowych (t.j. Dz.U. 2019, poz. 1509 ze zm.).

Ustawa z dnia 20 lipca 2018 r. - Prawo o szkolnictwie wyższym i nauce (t.j. Dz.U. 2019, poz. 276 ze zm.).

\section{ORzeCZnictwo}

Uchwała SN z dnia 29 grudnia 1971 r., III CZP 87/71, OSNCP 1972, nr 6, poz. 104.

Uchwała SN z dnia 9 listopada 2017 r., III CZP 43/17, Legalis nr 1682591.

Wyrok SA w Krakowie z dnia 28 września 1994 r., I ACa 464/99, TPP 2000, nr 3. 
Wyrok SA w Krakowie z dnia 28 września 1999 r., I ACa 464/99, Legalis nr 877847.

Wyrok SA w Warszawie z dnia 29 maja 2000 r., I ACa 1617/99, LEX nr 49243.

Wyrok SA w Warszawie z dnia 2 lutego 2011 r., I ACa 909/10, LEX nr 1120187.

Wyrok SA w Warszawie z dnia 5 lutego 2014 r., I ACa 1520/13, Legalis nr 797483.

Wyrok SA w Katowicach z dnia 25 lutego 2014 r., V ACa 690/13, Legalis nr 831368.

Wyrok SN z dnia 9 lipca 1971 r., II CR 220/71, OSNCP 1972, nr 1, poz. 19.

Wyrok SN z dnia 29 października 1971 r., II CR 455/71, OSN 1972, nr 4, poz. 77.

Wyrok SN z dnia 30 sierpnia 1974 r., I CR 384/74, OSNCP 1977, nr 10, poz. 161.

Wyrok SN z dnia 19 stycznia 1982 r., IV CR 500/81, OSNCP 1982, nr 9-10, poz. 123.

Wyrok SN z dnia 14 listopada 1986 r., II CR 295/86, OSNCP 1988, nr 2-3, poz. 40.

Wyrok SN z dnia 22 września 1995 r., III CZP 118/95, OSPiKA 1996, nr 4, poz. 78.

Wyrok SN z dnia 22 grudnia 1997 r., II CKN 546/97, OSNIC 1998, nr 7-8, poz. 19.

Wyrok SN z dnia 28 października 1998 r., II CKN 25/98, OSN 1999, nr 4, poz. 80.

Wyrok SN z dnia 23 maja 2002 r., IV CKN 1076/00, Legalis nr 55858.

Wyrok SN z dnia 7 marca 2003 r., I CKN 100/01, Legalis nr 58171.

Wyrok SN z dnia 15 kwietnia 2004 r., IV CK 284/03, Legalis nr 73102.

Wyrok SN z dnia 10 listopada 2005 r., V CK 314/05, LEX nr 186727.

Wyrok SN z dnia 11 stycznia 2007 r., II CSK 392/06, OSP 2009, nr 5, poz. 55.

Wyrok SN z dnia 24 września 2008 r., II CSK 126/08, Legalis nr 118211.

Wyrok SN z dnia 29 czerwca 2011 r., III SK 1/11, Legalis nr 492264.

Wyrok SN z dnia 5 kwietnia 2013 r., III CSK 198/12, OSNC 2013, nr 12, poz. 141.

Wyrok SN z dnia 11 sierpnia 2016 r., I CSK 419/15, Legalis nr 1507540.

Wyrok SO we Wrocławiu z dnia 23 września 2014 r., I C 1765/12, Legalis nr 2170530.

\section{SUMMARY}

The issues concerned with personal interests of a public university involve two aspects, which are currently subjected to significant transformation. The first one is the issue of personal interests granted to legal persons - the institiutions of civil law, regulated in the Civil Code. The second element refers to the public law, in terms of the public university regulated in the so-called Constitution for Science, i.e. the Law on Higher Education and Science. With reference to a fact that the public university has a legal presonality, it is entitled to personal rights as the subject of civil law. It means that these interests are subjected to protection provided for in the Civil Code. In consequence, in case of illegal threat or infringement of personal interests, the public university can effectively come up with claims provided for in Articles 24 and 448 of the Civil Code.

Keywords: civil law; personal interests; legal person; public university; Law on Higher Education and Science

\section{STRESZCZENIE}

Zagadnienie dotyczące dóbr osobistych uczelni publicznej łączy w sobie dwa aspekty podlegające w ostatnim czasie znaczącym przemianom. Pierwszy z nich dotyczy dóbr osobistych przysługujących osobom prawnym, a więc instytucji prawa cywilnego uregulowanej w przepisach Kodeksu cywilnego. Drugi element dotyczy pojęcia z zakresu prawa publicznego - uczelni publicznej, uregulowanego w tzw. Konstytucji dla Nauki, czyli ustawie Prawo o szkolnictwie wyższym i nauce. W związku z tym, że uczelnia publiczna posiada osobowość prawną, przysługują jej dobra osobiste jako podmiotowi prawa cywilnego. Oznacza to, że dobra te podlegają również ochronie przewi- 
dzianej w przepisach Kodeksu cywilnego. W konsekwencji, w razie bezprawnego zagrożenia lub naruszenia dobra osobistego, uczelnia publiczna może skutecznie występować z roszczeniami przewidzianymi w art. 24 i 448 k.c.

Słowa kluczowe: prawo cywilne; dobra osobiste; osoba prawna; uczelnia publiczna; Prawo o szkolnictwie wyższym i nauce 